\title{
Genetic variability of the S1 subunit of enteric and respiratory bovine coronavirus isolates
}

\author{
S. VILČEK ${ }^{1}$, A. JACKOVÁ ${ }^{1}$, M. KOLESÁROVÁ ${ }^{2}$ M. VLASÁKOVÁ ${ }^{1}$
}

\begin{abstract}
${ }^{1}$ University of Veterinary Medicine and Pharmacy, Komenského 73, 04001 Košice, Slovak Republic; ${ }^{2}$ Faculty of Science, P. J. Šafarik
\end{abstract} University, Košice, Slovak Republic

Received December 5, 2016; accepted December 16, 2016

\begin{abstract}
Summary. - Bovine coronavirus $(\mathrm{BCoV})$ is considered an important pathogen in cattle worldwide. It is a causative agent of enteric and respiratory diseases of cattle. The S1 subunit of the viral S glycoprotein is responsible for virus binding to host-cell receptors, induction of neutralizing antibody and hemagglutinin activity. The entire S1 genomic region (2304 bp) of two enteric bovine coronavirus isolates from Austria, one respiratory and one enteric isolate from Slovakia were analyzed at the genetic level. The comparative analysis of those four isolates revealed $97.1-98.6 \%$ similarity at the nucleotide and $95.6-98.6 \%$ at the amino acid level. No differences between enteric and respiratory isolates were observed at the genetic level. The isolates were clustered in the phylogenetic tree with European isolates independently of their enteric or respiratory origin.
\end{abstract}

Keywords: bovine coronavirus; S1 subunit; molecular characterization; phylogenetic analysis

Bovine coronavirus ( $\mathrm{BCoV}$ ) belongs to the genus Coronavirus of the family Coronaviridae. The virus is responsible for enteric and respiratory diseases of cattle such as severe diarrhea in newborn calves, winter dysentery in adult cattle and respiratory tract infections in calves and feedlot cattle (Saif et al., 1991; Boileau and Kapil, 2010; Saif, 2010). In dairy herds coronavirus infection, especially in winter, leads to a marked reduction in milk production with significant economic loss.

The bovine coronavirus genome consists of a linear, positive-sense, single stranded RNA $31 \mathrm{~kb}$ in length. The virion contains five structural proteins, namely nucleocapsid (N) protein, the transmembrane $(\mathrm{M})$ protein, the small envelope (E) protein, the hemagglutinin-esterase (HE) protein and the spike (S) protein. The $S$ glycoprotein is important for viral entry and pathogenesis. This protein is cleaved into S1 (N-terminal) and S2 (C-terminal) subunits (Abraham et al., 1990). The S1 subunit is responsible for virus binding to hostcell receptors (Kubo et al., 1994), induction of neutralizing

E-mail: vilcek@uvm.sk; phone: +421-915-984-654.

Abbreviations: $\mathrm{BCoV}=$ bovine coronavirus antibody (Yoo and Deregt, 2001) and hemagglutinin activity (Schultze et al., 1991). Amino acid mutations within S1 reflect changes of antigenicity and viral pathogenicity (Ballesteros et al., 1997). The S1 nucleotide sequences were often used for phylogenetic studies (Park et al., 2006; Martinez et al., 2012; Fulton et al., 2013) and molecular epidemiology (Liu et al., 2006; Bidokhti et al., 2012).

To our best knowledge, there is no information on the molecular genetic analysis of any $\mathrm{BCoV}$ isolates originating from Austria and Slovakia. To analyse the differences between selected enteric and respiratory isolates originating from these countries, the entire gene region for S1 subunit was sequenced and compared with representative strains deposited in GenBank.

Four clinical samples were selected to study genetic variability of the entire S1 subunit (2304 bp). The isolate SKCrevo originated from the enteric tract of cattle with diarrhea in Slovakia. The BCoV isolate SK21735 originating from the respiratory tract of cattle with respiratory problems in Slovakia was provided by the diagnostic laboratory of the State Veterinary Institute in Bratislava. The fecal samples AT13 (3595/04) and AT15 (3600/04) were collected during a survey for BCoV in Austrian cattle (Klein et al., 2009). 
Table 1. PCR primers used for the amplification of S1 gene

\begin{tabular}{|c|c|c|}
\hline Primer & Sequence $\left(5^{\prime}-3^{\prime}\right)$ & $\begin{array}{l}\text { Pos. in Mebus } \\
\text { U00735.2 }\end{array}$ \\
\hline S11 & TTG CGG TCA TAA TTA TTG TAG & $23553-23573$ \\
\hline S11R & TTA CAA GTC AAA GGC ATG AC & $24398-24379$ \\
\hline S12 & GAT ACA GGT GTT GTT TCC TG & $24199-24218$ \\
\hline S12R & AGT AGA AGG ATT AAA CCT GC & $24981-24962$ \\
\hline S13 & ATG GTA TGT GTT TTT CCA GC & $24788-24807$ \\
\hline S13R & ATA CCT TGG CCA GTA ATA CC & $25571-25552$ \\
\hline S14 & GCA TGA TGT TAA TAG TGG TAC & $25458-25478$ \\
\hline S14R & ATA GCA GAT CTA CTG GAA AC & $26387-26368$ \\
\hline
\end{tabular}

Total RNA was isolated using TRIzol Reagent (Life Technologies, USA) from $200 \mu$ l of original clinical sample according to the manufacturer's instruction and dissolved in $20 \mu \mathrm{l}$ of molecular grade water (Merck, GmbH, Germany).

The cDNA was synthesized in a $25 \mu$ reaction mixture comprising $5 \mu \mathrm{l}$ of isolated RNA, $5 \mu \mathrm{mol} / \mathrm{l}$ of random hexamers (Invitrogen, USA), $200 \mu \mathrm{mol} / 1 \mathrm{dNTPs}, 200 \mathrm{U}$ Moloney Murine reverse transcriptase with 1x RT buffer (Finnzymes, Inc., USA), 20 U RNase inhibitor (Invitrogen, USA) and molecular grade water (Merck, GmbH, Germany). The mixture was incubated at $65^{\circ} \mathrm{C}$ for $5 \mathrm{~min}$ and then chilled on ice to destroy RNA secondary structure. Subsequently, the mixture was incubated at $37^{\circ} \mathrm{C}$ for $60 \mathrm{~min}$ to synthesize cDNA.
The entire length of the S1 subunit (2304 bp) was sequenced from four overlapping PCR amplicons. The primers used in the PCR assays are listed in Table 1. The PCR reaction mixture $(50 \mu \mathrm{l})$ contained 1x Phusion HF Buffer (Finnzymes, Finland), $200 \mu \mathrm{mol} / \mathrm{l} \mathrm{dNTPs}$ (Invitrogen, USA), $0.3 \mu \mathrm{mol} / \mathrm{l}$ of each primer, 1 U Phusion High Fidelity DNA polymerase (Finnzymes, Finland), $4 \mu \mathrm{l}$ cDNA and molecular grade water (Merck, GmbH, Germany). The PCR was run with the following thermal profile: 1 cycle at $94^{\circ} \mathrm{C}$ for $2 \mathrm{~min}$, and 37 cycles with denaturation at $94^{\circ} \mathrm{C}$ for $1 \mathrm{~min}$, annealing at $53^{\circ} \mathrm{C}$ for $1 \mathrm{~min}$, extension at $72^{\circ} \mathrm{C}$ for $1 \mathrm{~min}$, and final extension at $72^{\circ} \mathrm{C}$ for $5 \mathrm{~min}$.

PCR amplicons were sequenced in both directions using Sanger's method employing fluorescently labelled ddNTPs by a commercial company (Microsynth Austria GmbH, Austria). The chromatograms were checked and edited by the computer program SeqMan (Lasergene, DNASTAR, Inc., USA). The nucleotide sequences were deposited into GenBank under Acc. Nos. KY612617-KY612620. The alignment of sequences was carried out by the computer program MegAlign (Lasergene, DNASTAR, Inc., USA). The sequences of other enteric and respiratory isolates deposited in GenBank were also used for the comparative computer analysis. The phylogenetic tree was constructed by the neighbor-joining method using the Kimura-2 parameter incorporated in the computer package program MEGA 6 (Tamura et al., 2013).

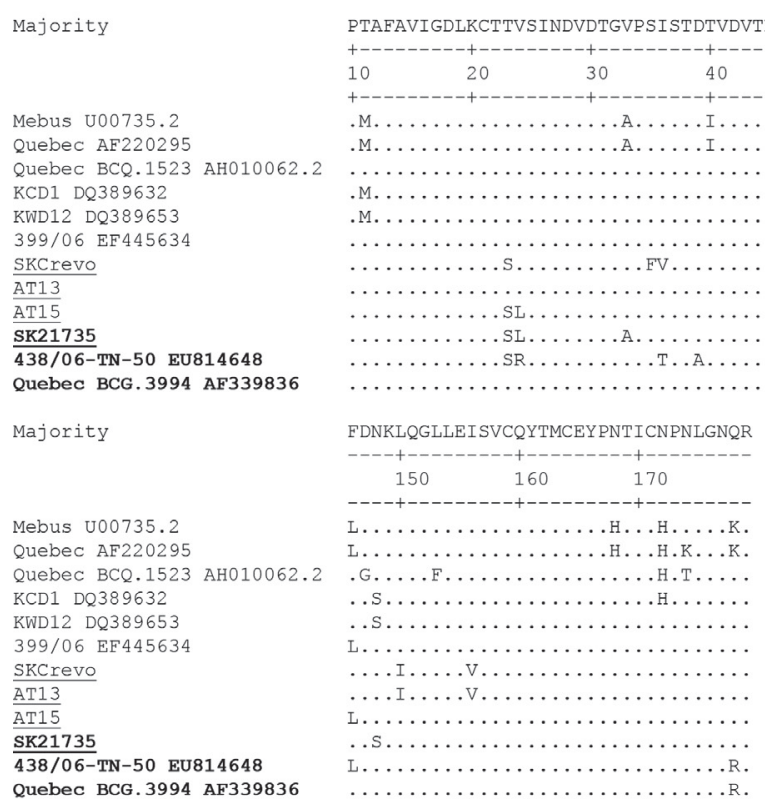

Alignment of the $\mathrm{S} 1$ deduced amino acid sequence in three variable regions

Positions of amino acids in S1: 10-118, 146-179, 458-531 as identified by Hasoksuz et al. (2002). Underlined isolates were analyzed in this work; other isolates were taken from GenBank. Respiratory isolates are in bold.

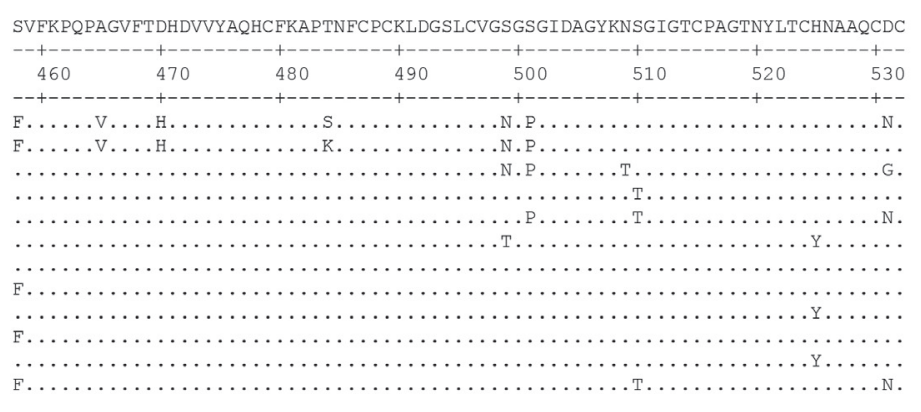

Fig. 1 


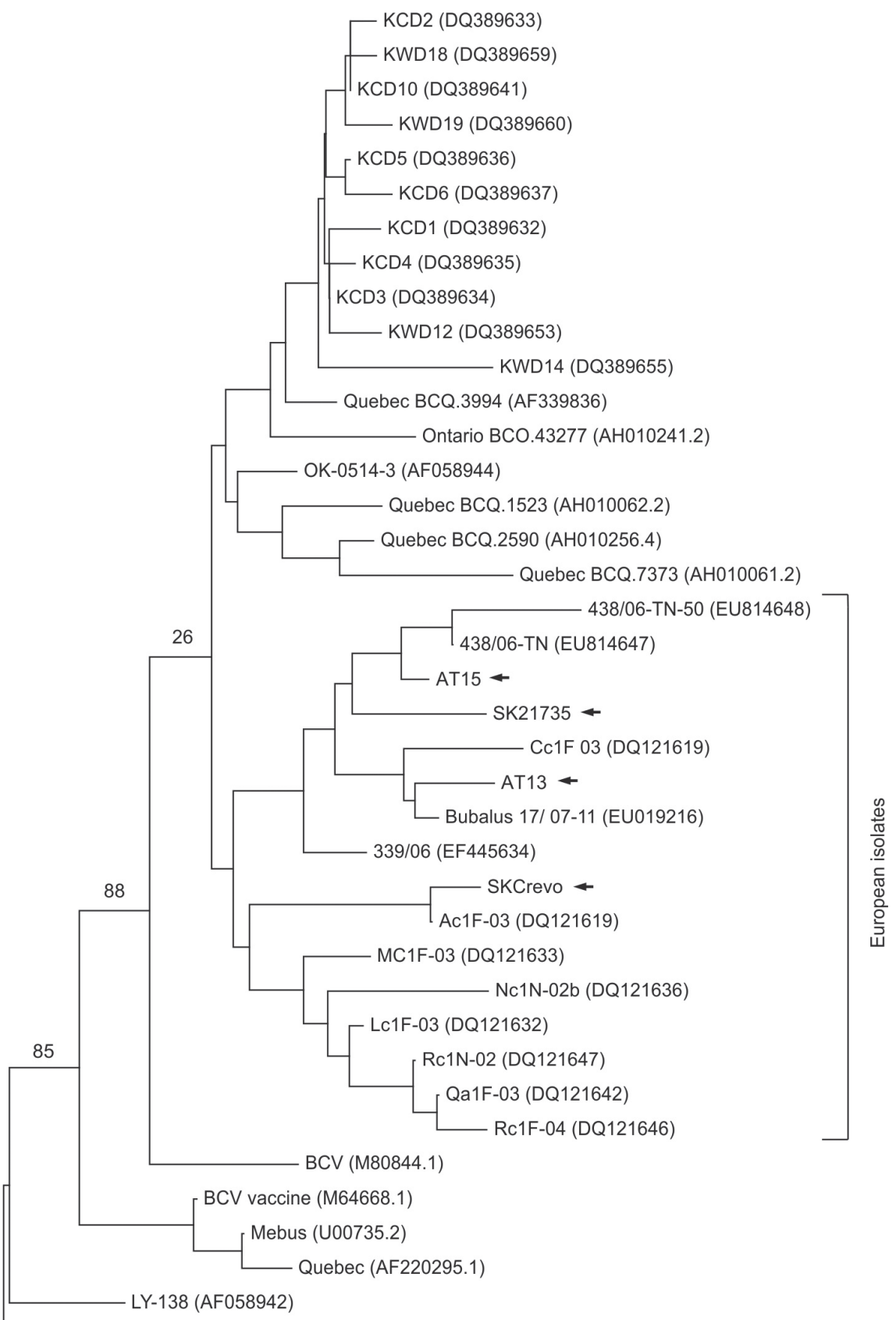

CaenBCV (DQ355400)

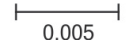

Fig. 2

Phylogenetic tree of BCoV isolates constructed using 624 bp of S1 nucleotide sequences Arrows indicate the isolates analyzed in this work. Sequences taken from GenBank are with Acc. Nos. in brackets.

The comparison of our four entire $\mathrm{S} 1$ sequences $(2304 \mathrm{nt}$ encoding 768 aa) between each other revealed $97.1-98.6 \%$ similarity at the nucleotide and $95.6-98.6 \%$ at the amino acid level. Comparably high genetic similarity was also observed between $\mathrm{BCoV}$ isolates analyzed in other laboratories. For example, the amino acid identity in the $\mathrm{S} 1$ region was over $96 \%$ between Scandinavian isolates (Liu et al., 2006), over 97.5 \% between Croatian isolates (Lojkic et al., 2015), simi- 
lar as between isolates from Korea (Park et al., 2006). The amino acid substitutions in isolates analyzed in our work were concentrated in three regions at positions $10-118$, 146-179 and the hypervariable region (pos. 458-531) as identified by Hasoksuz et al. (2002) (Fig. 1). The deletion of six amino acids in the hypervariable region found in Brazilian isolates (Brandao et al., 2006) was not identified in the isolates we analyzed. The amino acid stretch KRRSRR, which is a signal sequence for the proteolytic cleavage of $S$ protein at residue 768 into subunits S1 and S2, was conserved in all four isolates.

When our sequences were compared with sequences deposited in GenBank, we did not find amino acid mutations in the $\mathrm{S} 1$ gene region reported as typical for enteric or respiratory isolates. Differentiating between enteric and respiratory $\mathrm{BCoV}$ isolates is a problem, however, with contradictory conclusions within in the scientific literature. While several laboratories did not confirm consistent differences between isolates originating from enteric and respiratory organs (Liu et al., 2006; Decaro et al., 2008; Lojkic et al., 2015), others have found significant differences (Chouljenko et al., 2001; Gelinas et al., 2001; Hasoksuz et al., 2002; Park et al., 2006; Fulton et al., 2013). Most probably a comparative sequence analysis of the entire genome of a greater number of coronavirus isolates, including antigenic studies, will definitely resolve the issue.

Our analysis has confirmed that the distribution of isolates is similar in phylogenetic trees constructed with entire $(2,304$ bp) or partial (624 bp) S1 sequences (data not shown). Due to insufficient amount of sequences available for the entire S1 region, the $624 \mathrm{bp}$ fragment (position 16-639) was selected for further phylogenetic study (Fig. 2). The analyses revealed that European isolates were clustered in a separate branch from non-European isolates. $\mathrm{BCoV}$ isolates from Austria and Slovakia were most closely located with isolates originating from Italy and selected isolates from Denmark, far from the reference strain Mebus or a vaccine strain. The phylogenetic tree indicated common evolution of bovine coronaviruses on the European continent.

The clustering of isolates in the phylogenetic tree depended rather on the geographic origin of samples than on their enteric or respiratory origin. For example, the Slovakian respiratory isolate SK21735 was clustered with enteric European isolates. The Canadian respiratory isolate Quebec BCG_3994 was clustered closer to Canadian enteric isolates. This observation indicates that there are not enough characteristic mutations in the $624 \mathrm{bp}$ fragment to provide phylogenetic evidence to distinguish enteric and respiratory isolates.

This study of four BCoV isolates from Austria and Slovakia is the first attempt at a genetic analysis of bovine coronavirus from this geographic region. The viral isolates were phylogenetically related to European BCoV isolates. Our data provided evidence that enteric and respiratory isolates of BCoV cannot be differentiated by molecular analysis of the $\mathrm{S} 1$ subunit of their spike proteins.

Acknowledgement. We thank Professor Karin Möstl, University of Veterinary Medicine,Vienna for providing BCoV RNA isolated from cattle in Austria for genetic analysis. We would like to thank Peter Nettleton, Edinburgh for critical reading of the manuscript and correction of English grammar. This work was supported by project INFEKTZOON (ITMS 26220120002).

\section{References}

Abraham S, Kienzle TE, Lapps W, Brian DA (1990): Deduced sequence of the bovine coronavirus spike protein and identification of the internal proteolytic cleavage site. Virology 176, 296-301. https://doi.org/10.1016/00426822(90)90257-R

Ballesteros MI, Sanchez CM, Enjuanez I (1997): Two amino acid changes of the $\mathrm{N}$-terminus of transmissible gastroenteritis coronavirus spike protein result in the loss of enteric tropism. Virology 227, 378-388. https://doi.org/10.1006/ viro.1996.8344

Bidokhti MRM, Traven M, Ohlson A, Baule C, Hakhverdyan M, Belak S, Liu L, Alenius S (2012): Tracing the transmission of bovine coronavirus infections in cattle herds based on S gene diversity. Vet. J. 193, 386-390. https://doi. org/10.1016/j.tvjl.2011.12.015

Boileau MJ, Kapil S (2010): Bovine coronavirus associated syndromes. Vet. Clin. Food Anim. 26, 123-146. https://doi. org/10.1016/j.cvfa.2009.10.003

Brandao PE, Gregori F, Richtzenhain LJ, Rosales CAR, Villarreal LYB, Jerez JA (2006): Molecular analysis of Brazilian strains of bovine coronavirus $(\mathrm{BCoV})$ reveals a deletion within the hypervariable region of the S1 subunit of the spike glycoprotein also found in human coronavirus OC43. Arch. Virol. 151, 1735-1748. https://doi. org/10.1007/s00705-006-0752-9

Chouljenko VN, Liu XQ, Storz J, Kousoula KG, Gorbalenya AE (2001): Comparison of genome and predicted amino acid sequences of respiratory and enteric bovine coronaviruses isolated from the same animal with fatal shipping pneumonia. J. Gen. Virol. 82, 2927-2933. https://doi. org/10.1099/0022-1317-82-12-2927

Decaro N, Mari V, Desario C, Campolo M, Elia G, Martella V, Greco G, Cirone F, Colaianni ML, Cordioli P, Buonavoglia C (2008): Severe outbreak of bovine coronavirus infection in dairy cattle during the warmer season. Vet. Microbiol. 126, 30-39. https://doi.org/10.1016/j. vetmic.2007.06.024

Fulton RW, Ridpath JF, Burge LJ (2013): Bovine coronavirus from the respiratory tract: Antigenic and genetic diversity. Vaccine 31, 886-892. https://doi.org/10.1016/j. vaccine.2012.12.006

Gelinas AM, Sasseville AM, Dea S (2001): Identification of specific variations within the HE, S1 and ORF4 genes of bovine 
coronaviruses with enteric and respiratory diseases in dairy cattle. Adv. Exp. Med. Biol. 494, 63-67. https://doi. org/10.1007/978-1-4615-1325-4_9

Hasoksuz M, Sreevatsan S, Cho KO, Hoet AE, Saif LJ (2002): Molecular analysis of the $\mathrm{S} 1$ subunit of the spike glycoprotein of respiratory and enteric bovine coronavirus isolates. Virus Res. 84, 101-109. https://doi.org/10.1016/S01681702(02)00004-7

Klein D, Kern A, Lapan G, Benetka V, Mostl K, Hassl A, Baumgartner W (2009): Evaluation of rapid assays for the detection of bovine coronavirus, rotavirus A and Crystosporidium parvum in faecal samples of calves. Vet. J. 182, 484-486. https://doi.org/10.1016/j.tvjl.2008.07.016

Kubo H, Yamada YK, Taguchi F (1994): Localization of neutralizing epitope and the receptor-binding site within the aminoterminal 330 amino acids of the murine corovirus spike protein. J. Virol. 68, 5403-5410.

Liu L, Hagglund S, Hakhverdyan M, Alenius S, Larsen LE, Belak S (2006): Molecular epidemiology of bovine coronavirus on the basis of comparative analysis of the $\mathrm{S}$ gene. J. Clin. Microbiol. 44, 957-960. https://doi.org/10.1128/ JCM.44.3.957-960.2006

Lojkic I, Kresic N, Simic I, Bedekovic T (2015): Detection and molecular characterization of bovine corona and toroviruses from Croatian cattle. BMC Vet. Res. 11, Article No 202. https://doi.org/10.1186/s12917-015-0511-9

Martinez N, Brandao PE, de Souza SP, Barrera M, Santana N, de Arce HD, Perez LJ (2012): Molecular and phylogenetic analysis of bovine coronavirus based on the spike glyco- protein gene. Inf. Gen. Evol. 12, 1870-1878. https://doi. org/10.1016/j.meegid.2012.05.007

Park SJ, Jeong C, Yoon SS, Choy HE, Saif LJ, Park SH, Kim YJ, Jeong JH, Park SI, Kim HH, Lee BJ, Cho HS, Kim SK, Kang MI, Cho KO (2006): Detection and characterization of bovine coronavirus in fecal specimens of adult cattle with diarrhea during the warmer seasons. J. Clin. Microbiol. 44, 3178-3188. https://doi.org/10.1128/JCM.02667-05

Saif IJ (2010): Bovine respiratory coronaviruses. Vet. Clin. Food Anim. 26, 349-364. https://doi.org/10.1016/j. cvfa.2010.04.005

Saif IJ, Brock KV, Redman DR, Kohler EM (1991): Winter dysentery in dairy herds: electron microscopic and serological evidence for an association with coronavirus infection. Vet. Rec. 128, 447-449. https://doi.org/10.1136/ vr.128.19.447

Schultze B, Gross HJ, Brossmer R, Herrler G (1991): The S protein of bovine coronavirus is a hemagglutinin recognizing 9-Oacetylated sialic acid as a receptor determinant. J. Virol. 65, 6233-6237.

Tamura K, Stecher G, Peterson D, Filipski A, Kumar S (2013): MEGA 6: Molecular Evolutionary Genetics Analysis version 6.0. Mol. Biol. Evol. 30 2725-2729. https://doi. org $/ 10.1093 / \mathrm{molbev} / \mathrm{mst} 197$

Yoo D, Deregt D (2001): A single amino acid change within antigenic domain II of the spike protein of bovine coronavirus confers resistance to virus neutralization. Clin. Diagn. Lab. Immunol. 8, 297-302. https://doi.org/10.1128/ cdli.8.2.297-302.2001 